\title{
THE RIGHT TO ACCESS LEGAL REPRESENTATION AND ADMISSIBILITY TO THE INTERNATIONAL CRIMINAL COURT: WALKING THE TIGHTROPE BETWEEN LEGITIMACY AND EFFECTIVENESS
}

\author{
Holly Kendall
}

\begin{abstract}
Ratification of the Rome Statute was a significant step in developing international rule of law. The International Criminal Court (ICC) now faces challenges in balancing its judicial character with maintaining the ongoing support of states. The contradictory outcomes in decisions on the admissibility of the cases against Saif Al-Islam Gaddafi and Abdullah AlSenussi raise questions about the relevance of access to legal representation for admissibility to the ICC. This paper argues that the purposes of the ICC require it to consider access to legal representation in its decisions on admissibility, that the Rome Statute permits its consideration and that the Court should take a pluralist approach that ensures that basic standards of access to legal representation are met while gradually developing higher standards of international criminal justice. In this sense, it could walk the tightrope between legitimacy and effectiveness.
\end{abstract}

\section{A. INTRODUCTION}

Complementarity is a central element of the Statute of the International Criminal Court (Rome Statute $)^{1}$ that was intended to balance state sovereignty against impunity. ${ }^{2}$ Complementarity means that if a state is unwilling or unable to prosecute an individual accused of an international crime, the International Criminal Court ('ICC' or 'the Court') may try the accused. ${ }^{3}$ The trials of Saif Al-Islam Gaddafi and Abdullah Al-Senussi have raised questions about whether access to legal representation should be considered in determining whether a state is unwilling or unable to try an accused. Prior to determinations of admissibility by the ICC neither Gaddafi nor Al-Senussi had access to legal representation for the domestic proceedings against them. The ICC held the case against Gaddafi admissible whereas the case against Al-Senussi was not. ${ }^{4}$ This paper considers the relevance of access to legal representation to admissibility of a case to the ICC.

\footnotetext{
"LLM University College London. I thank Dr Douglas Guilfoyle for his support and guidance and Nikolaos Pavlopoulos and Lea Raible for their helpful comments.

${ }^{1}$ Rome Statute of the International Criminal Court (adopted 17 July 1998, entered into force 1 July 2002) 2187 UNTS 3 (Rome Statute).

${ }^{2}$ Report of the Ad Hoc Committee on the Establishment of an International Criminal Court', United Nations General Assembly Official Records, Fiftieth Session (New York, 1995) UN Doc 22 A/50/22 (Ad Hoc Committee) para 37.

${ }^{3}$ Rome Statute (n 1) art 17.

${ }^{4}$ Prosecutor $v$ Gaddafi and Al-Senussi (admissibility of the case against Gaddafi) ICC-01/11/-01/11 (31 May 2013) (Gaddafi Admissibility Decision) para 213; Prosecutor $v$ Gaddafi and Al-Senussi (admissibility of the case against Al-Senussi) ICC-01/11-01/11 OA 6 (24 July 2014) (Al-Senussi Admissibility Appeal Decision) para 180.
} 
Section B addresses the theoretical aspects of the purpose of the ICC and how the provision of procedural justice is essential to fulfillment of its judicial function. Section $\mathrm{C}$ explores how the Rome Statute and its interpretation through the ICC implements theory in practice. It demonstrates that complementarity requires the Court to take into account the accused's right to access legal representation, but that this must be done in a way that maintains the legitimacy and effectiveness of the ICC.

As an international legal institution, the ICC's effectiveness is dependent not only on fulfilling its function of providing justice but also on maintaining the support of states. Considerations of effectiveness may influence the Court's discretion. The ICC needs to be cognisant of the impact of the application of complementarity on the effectiveness of the Court and legitimacy of international criminal justice. Consideration of the accused's right to access legal representation is essential to ensuring the legitimacy of the Court, but this must be balanced against the appearance of judicial imperialism and impeding the benefits of local justice. To maintain the integrity of international justice, the ICC must require a base level of access to legal representation for the accused in domestic proceedings that is accepting of different legal contexts. ${ }^{5}$ This will allow for the development of higher standards of international criminal justice.

\section{B. THEORETICAL ASPECTS: THE PURPOSE OF THE ICC AND WHY IT MATTERS FOR THE CONSIDERATION OF THE ACCUSED RIGHTS}

The preamble and context of the drafting of the Rome Statute suggest a range of purposes for the establishment of the ICC. The purposes of providing international justice and contributing to the rule of law, preventing impunity, deterrence, and establishment of a permanent court are relevant to whether the Court should consider the accused's rights in determining admissibility. It is an inherent function of a court to provide justice. Access to legal representation is at the very least a safeguard of procedural justice. This section establishes how justice is relevant to the purpose of the ICC and, as a second step, why the Court's purpose is relevant to procedural questions.

\section{Types of Justice}

International criminal justice attempts to implement various forms of justice. Relevantly these include retributive justice, justice for victims, denunciation, deterrence and

\footnotetext{
${ }^{5}$ There is debate about the impact that the ICC has on domestic proceedings. This paper assumes that states will take some notice of ICC decisions.
} 
procedural justice. Retributive justice seeks to punish those that have committed international crimes on the basis that the offenders deserve punishment for what they have done. ${ }^{6}$ Access to legal representation is relevant as it assists the Court to determine whether the individual has committed an offence, whether there is a defence, and whether there are any mitigating factors. Justice for victims seeks to recognise the harm to the individuals that have suffered and prevent vigilante justice. Given the magnitude and severity of international crimes, a failure to prosecute and convict can be seen as injustice by victims. Bringing international criminals to justice before the ICC also enhances denunciation and deterrence. To provide justice to victims, denunciation, and deterrence, procedural justice for the alleged perpetrator is crucial. Procedural justice protects the rights of the accused to ensure that the perpetrator is convicted rather than a scapegoat in a show trial. Justice for victims does not guarantee a conviction; it is a procedural guarantee enshrining that parties will be investigated and, where relevant, prosecuted. ${ }^{7}$ Procedural justice seeks to ensure that the responsible party is prosecuted. Similarly, denunciation and deterrence are only effective if the Court prosecutes and convicts those that are responsible; otherwise, it will lack legitimacy and effectiveness as it will fail to provide any form of justice. Procedural justice is thus not only valuable for its own sake but also serves as a stepping stone for other types of justice.

\section{Purpose of the ICC}

\section{a) International criminal justice}

International criminal justice is the provision of accountability and punishment for international crimes. The preamble of the Rome Statute affirms that 'the most serious crimes of concern to the international community as a whole must not go unpunished and that their effective prosecution must be ensured...' When a national jurisdiction prosecutes the accused for international crimes, they act as organs and on behalf of the international community irrespective of whether the act is also a domestic crime. ${ }^{8}$ Recognition that the prosecution of international crimes is carried out on behalf of the international community means that the obligations to investigate and prosecute in the Rome Statute are obligations owed to other states parties (and their people). This empowers the ICC 'to assess the effective

\footnotetext{
${ }^{6}$ Robert Cryer and others, An Introduction to International Criminal Law and Procedure (2nd edn, CUP 2010) 24.

${ }^{7}$ Luke Moffett, 'Realising Justice for Victims Before the International Criminal Court' (2014) 6 International Crimes Database Brief <http://www.internationalcrimesdatabase.org/upload/documents/20140916T170017ICD\%20Brief\%20-\%20Moffett.pdf> accessed 27 July 2015.

${ }^{8}$ Attorney-General of Israel v Eichmann, Judgment of the Supreme Court of 29 May 1962, 36 ILR 277, 291,293; Paul JIM de Waart, Erik Denters and Nico Schrijver (eds), Reflections on International Law from the Low Countries: In Honour of Paul de Waart (Martinus Nijhoff 1998) 251; Jann K Kleffner, Complementarity in the Rome Statute and National Criminal Jurisdictions (OUP 2008) 26.
} 
implementation of this obligation as sole and ultimate arbiter'. ${ }^{9}$ In Tadić, the International Criminal Tribunal for Yugoslavia held that '... the sovereign rights of [s]tates cannot and should not take precedence over the right of the international community to act appropriately $\ldots .{ }^{10}$ This should include the consideration of the accused's rights.

Heller objects that this is contrary to the intention of the Parties that did not wish for the ICC to carry out assessments of national judicial systems as evidenced by the travaux préparatoires. ${ }^{11}$ The Parties did not want the ICC to carry out assessments of a national judicial system, but addressed this issue in the drafting of Article 17 that limits the Court's assessment to 'the case', 'the proceedings', or 'in a particular case'. ${ }^{12}$ Any assessment of a specific case may lead to consideration of systemic factors. ${ }^{13}$ Further, Heller's position fails to recognise the importance of maintaining the legitimacy of the international criminal justice system through symbolic validation. Symbolic validation refers to the reinforcement of the law's authority by grounding it in the social order. In the case of the ICC, though not every perpetrator is prosecuted, its enforcement of international criminal law through judgments and sentencing, where necessary, reinforces the authority of international criminal law in the social order. Symbolic validation is important to legitimacy because it communicates authority and signals significance in the overall system of social order. ${ }^{14}$ The Prosecutor has supported the role of symbolic validation by stating that 'it falls upon this Council and the international community to assist Libya to ensure that justice is not only done, but is seen to be effectively done'. ${ }^{15}$ If the ICC allows domestic courts, acting as international organs, to violate the rights of the accused it undermines the entire international criminal justice system as it replaces one kind of impunity with another. ${ }^{16}$

\footnotetext{
${ }^{9}$ Federica Gioia, 'State Sovereignty, Jurisdiction, and "Modern" International Law: The Principle of Complementarity in the International Criminal Court' (2006) 19 LJIL 1095, 1100-1101.

${ }^{10}$ Prosecutor v Tadic (Jurisdiction) ICTY-94-1 (10 August 1995) para 42.

${ }^{11}$ Kevin Jon Heller, 'The Shadow Side of Complementarity: The Effect of Article 17 of the Rome Statute on National Due Process' (2006) 17 Criminal Law Forum 281.

${ }^{12}$ Rome Statute (n 1) art 17.

${ }^{13}$ Prosecutor v Gaddafi and Al-Senussi (admissibility of the case against Al-Senussi) ICC-01/11/-01/11(11 October 2013) (Al-Senussi Admissibility Decision) para 202 Separate opinion of Sung Hyun Song; Prosecutor $v$ Gaddafi and Al-Senussi (admissibility of the case against Gaddafi) ICC-01/11/-01/11 OA 4 (21 May 2014) (Gaddafi Admissibility Appeal Decision) para 26; Mohamed El Zeidy, The Principle of Complementarity in International Criminal Law: Origin, Development, and Practice (Martinus Nijhoff 2008) 166.

${ }^{14}$ Thomas M Franck, Fairness in International Law and Institutions (OUP 1998) 30-41.

15 'Statement of the Prosecutor of the International Criminal Court, Fatou Bensouda, to the United Nations Security Council on the Situation in Libya, pursuant to UNSCR 1970 (2011)' (New York, 14 November 2013) $<$ www.icccpi.int/en_menus/icc/structure $\% 20$ of $\% 20$ the $\% 20$ court/office $\% 20$ of $\% 20$ the $\% 20$ prosecutor/reports $\% 20$ and $\% 20$ st atements/statement/Pages/Statement-UNSC-Nov2013.aspx> accessed 6 August 2014.

${ }^{16}$ Heller (n 11) 280.
} 
In the final paragraph of the preamble to the Rome Statute, the states parties resolve 'to guarantee lasting respect for and the enforcement of international justice'. This reflects that if the purpose of the ICC was merely to prevent impunity 'it would be a stimulus for show trials' ${ }^{17}$ Damaška highlights that:

[I]t would indeed be a disheartening irony if a justice system designed to contribute to the protection of human rights, could properly function only by disregarding humanistic values ... If the perception were to spread that the courts stack the deck against the accused, this realization would in the long run be more harmful to legitimacy than sporadic acquittals. The courts' constituencies, both global and local, might come to view them as administering only show trials and dispensing only secondrate justice. $^{18}$

Just as national courts can be too eager to convict an accused, so can the ICC to shield itself from criticism of failing to prevent impunity. This was evident in the conviction of Katanga on the basis of a re-characterisation of facts that violated the accused's right to be informed of the case against them. ${ }^{19}$ The credibility of the ICC is linked to its capacity to provide universal criminal justice without bias. ${ }^{20}$ This requires it to be publicly trusted to uphold the rule of law through credible application and impartial standards in a fair and consistent manner. ${ }^{21}$

\section{b) International rule of law}

Though not explicit in the language of the Rome Statute, the establishment of an international court serves the purpose of establishing and upholding the rule of law. ${ }^{22}$ The Rome Statute and associated international law set forth in advance the applicable law in general terms. The Court seeks to impose restrictions on the exercise of power in accordance with law and apply the law equally to all parties. ${ }^{23}$ Nonetheless, referrals to the ICC have a political dimension. Arbour argued that complementarity would favour rich developed countries against poor countries

\footnotetext{
${ }^{17}$ Ruti Teitel, 'Local Injustice: Why We Shouldn't Forget about Saif Gaddafi' (I.CONnect, 16 October 2012) <www.iconnectblog.com/2012/10/local-injustice-why-we-shouldnt-forget-about-saif-gaddafi/> accessed 9 January 2014.

${ }^{18}$ Mirjan Damaška, 'What Is the Point of International Criminal Justice?' 2008 Chicago-Kent L Rev 329, 355-6.

${ }^{19}$ Prosecutor $v$ Katanga and Chui (admissibility of the case against Katanga) ICC-01/04-01/07 OA 8 Appeals Chamber (25 September 2009) (Katanga) Dissenting Opinion of Judge van den Wyngaert, paras 9-132.

${ }^{20}$ Catherine Gegout, 'The International Criminal Court: Limits, Potential and Conditions for the Promotion of Justice and Peace' (2013) 34 Third World Q 800, 801.

${ }^{21}$ Steven C Roach, 'Legitimising Negotiated Justice: The International Criminal Court and Flexible Governance' (2013) 17 International Journal of Human Rights 619, 625.

${ }^{22}$ Cherie Boot 'Prospects and issues for the International Criminal Court' in Philippe Sands (ed) From Nuremberg to the Hague: The Future of International Criminal Justice (CUP 2003) 180.

${ }^{23}$ Brian Z Tamanaha 'The History and Elements of the Rule of Law' [2012] Sing JLS 232, 233.
} 
because it would be difficult to demonstrate that a state with a sophisticated and functional justice system was 'unwilling' or 'unable'. ${ }^{24}$ The caseload of the Court to date demonstrates that it is more likely that the Court will prosecute nationals and situations from the least powerful states. All situations relate to African nations. ${ }^{25}$ However, and somewhat contrasting with the argument above, four of these - the Democratic Republic of Congo, Uganda, Central African Republic and Mali - have been based on self-referrals by national governments consistent with state sovereignty. As an instrument of global governance, the ICC directly applies international law. ${ }^{26}$ The development of an international rule of law is limited by the influence of the inequality of power within the institutions and mechanisms of international law, but the application of law by the ICC demonstrates many of the elements needed for an international rule of law.

The ICC is simultaneously applying and developing the international rule of law. The jurisdiction of the ICC is established in the Rome Statute. Each decision of the Court applies the rule of law in making decisions on the basis of the Rome Statute and other applicable international law, also developing the international community's understanding of international criminal law. Without the traditional enforcement mechanism of a police force, the Court's contribution to the establishment of an international rule of law depends on the Court being perceived as a legitimate authority by its constituency which 'hangs almost entirely on the quality of their decisions and their procedures' ${ }^{27}$

Through the application of the principle of the rule of law, the ICC creates norms of international criminal justice. Complementarity allows the Court to define these international standards of justice. ${ }^{28}$ For example, the ICC's decisions provide guidance to domestic courts for prosecutorial standards required to prevent the ICC from determining that a matter is admissible to the Court. Ideally, the ICC will develop the standards of international criminal procedure to such an extent that national jurisdictions will be able to clearly identify and apply the standards that it demands in domestic trials of international crimes.

It is an essential element of procedural justice that the accused receives a fair trial. Consideration of the accused's access to legal representation in determining admissibility is

\footnotetext{
${ }^{24}$ William A Schabas, An Introduction to the International Criminal Court (CUP 2011) 196.

${ }^{25}$ Situations and cases (International Criminal Court) <http://icc-cpi.int/en_menus/icc/situations\%20and\%20cases/situations/Pages/situations\%20index.aspx> accessed 7 August 2014.

${ }^{26}$ de Waart, Denters and Schrijver (n 8) 253.

${ }^{27}$ Damaška (n 18) 345.

${ }^{28}$ Eric Blumenson, 'The Challenge of a Global Standard of Justice: Peace, Pluralism, and Punishment at the International Criminal Court' (2005) 44 Colum J Transnat'1 L 801, 804-05.
} 
consistent with the inherent powers of the court to provide procedural justice. As Gioia puts it:

[I]f we assume that the Court is meant to serve as an international body complementing national jurisdictions ... for the most serious crimes by abiding by the highest international human rights standards, allowing the ICC to remedy the failures of national courts in complying with due process standards seems entirely consistent with this role. ${ }^{29}$

c) Preventing impunity

The Court, based on the preamble, has identified the aim of the Rome Statute as 'to put an end to impunity' and to ensure that 'the most serious crimes of concern to the international community as a whole must not go unpunished'. ${ }^{30}$ The establishment of the Court was a response to dissatisfaction with other methods of dealing with international criminals that had resulted in impunity, extrajudicial killing, or show trials. ${ }^{31}$ This links the establishment of the Court with the purpose of providing retributive justice.

In relation to Gaddafi's trial, the former ICC Prosecutor took the position that the emphasis on impunity did not require consideration of the accused's rights. He stated 'we [the ICC] are not a system to monitor fair trials. We are a system to ensure no impunity. ${ }^{32}$ This approach is supported to some extent by consideration of the travaux préparatoires of the Rome Statute. Italy proposed a version of Article 17 that would have permitted the Court to consider whether "the said investigations or proceedings ... were or are conducted with full respect for the fundamental rights of the accused'. ${ }^{33}$ Heller argues that rejection of the Italian proposal demonstrates that states did not want the ICC to function as a supranational court of human rights, imposing its own practices and procedures on national criminal justice systems. ${ }^{34}$ The Court agrees. ${ }^{35}$ However, the travaux préparatoires are merely a subsidiary source of treaty interpretation and other interpretations are possible. ${ }^{36}$

In this case, the travaux préparatoires reflect disagreement between the Parties about whether the Court should take into consideration the rights of the accused. The Ad Hoc and

\footnotetext{
${ }^{29}$ Gioia (n 9) 1100-1101.

${ }^{30}$ Katanga (n 19) para 79.

${ }^{31}$ Cryer and others (n 6) 23.

32 Teitel, 'Local Injustice: Why We Shouldn't Forget about Saif Gaddafi' (n 17).

${ }^{33}$ Draft Proposal by Italy, UN Doc A/AC.249/1997/WG.3/IP.4, 5 August 1997.

${ }^{34}$ Heller (n 11) 255, 272, 281.

${ }^{35}$ Al-Senussi Admissibility Appeal Decision (n 4) para 226.

${ }^{36}$ Vienna Convention on the Law of Treaties (adopted 23 May 1969, entered into force 27 January 1980) 1155 UNTS 331 (VCLT), art 32.
} 
Preparatory Committees provide evidence of state concerns about sovereignty, constitutional guarantees in domestic systems against double jeopardy, and the concerns of France, the United Kingdom, and the United States that the ICC would function as a quasi-appellate court, passing judgments on the decisions and proceedings of national judicial systems. ${ }^{37}$ The Ad Hoc Committee envisioned this as being addressed by the Court making a case-by-case assessment. ${ }^{38}$ Other states, including the sixty states of the Like Minded Group, were committed to giving the ICC the power to intervene where domestic proceedings were ineffective. ${ }^{39}$

The failure of the Parties to agree to the explicit consideration of the availability of due process rights could be characterised as a deliberate lacuna for the purpose of achieving agreement. ${ }^{40}$ The Rome Statute was a product of compromise. ${ }^{41}$ Pursuit of a statute with the strongest protections for the accused would have attracted the opposition of a significant number of states, reducing the actual effectiveness of the Court. ${ }^{42}$ It is the role of the Court to settle disagreements, including disagreements unresolved in the Rome Statute. ${ }^{43}$ As a result, the Court has to fill the gap. ${ }^{44}$

Even if the sole purpose of the ICC was to prevent impunity, this requires justice. Impunity is defined as '[e]xemption from punishment or freedom from the injurious consequences of an action'. ${ }^{45}$ The prevention of impunity is not facilitated by punishing those that are not guilty of an offense. Conviction of an accused who has not perpetrated a crime does not prevent impunity. If anything, it will promote impunity, as the true perpetrator is more

\footnotetext{
${ }^{37}$ John T Holmes, 'The Principle of Complementarity' in Roy S Lee (ed) The International Criminal Court: The Making of the Rome Statute (Kluwer 1999) 41, 48; Ad Hoc Committee (n 2) para 43; 'Report of the Preparatory Committee on the Establishment of an International Court' Volume I (Proceedings of the Preparatory Committee during March-April and August 1996) United Nations General Assembly Official Records, Fiftieth Session (New York, 1995) (Preparatory Committee Vol I) UN Doc. A/51/22 paras 161, 172.

${ }^{38}$ Ad Hoc Committee (n 2) para 45.

${ }^{39}$ Sharon A Williams and William A Schabas 'Article 17 Issues of Admissibility' in Otto Triffterer and Kai Ambos (eds), Commentary on the Rome Statute of the International Criminal Court: Observers' Notes, Article by Article (2nd edn, Hart 2008) 610; Philippe Kirsch and Darryl Robinson 'Reaching Agreement at the Rome Conference' in Antonio Cassese, Paola Gaeta and John RWD Jones (eds), The Rome Statute of the International Criminal Court: A Commentary (OUP 2002) 69; Cryer and others (n 6) 147.

${ }^{40}$ Chester Brown, 'The Inherent Powers of International Courts and Tribunals' (2006) 76 BYIL 195, 202.

${ }^{41}$ Williams and Schabas (n 39) 625.

${ }^{42}$ Kirsch and Robinson (n 39) 87.

43 Yuval Shany, 'Part 1: The Concept of Jurisdiction and Admissibility in International Adjudication - a Theoretical Framework' (Hersch Lauterpacht Memorial Lectures, Cambridge, 28 February 2012) <www.lcil.cam.ac.uk/events/2012-lauterpacht-lectures-part-1-concept-jurisdiction-and-admissibilityinternational-adjudic> accessed 12 August 2014.

${ }^{44}$ Paola Gaeta, 'Inherent Powers of International Courts and Tribunals' in Lal Chand Vohrah and others, Man's Inhumanity to Man: essays on international law in honour of Antonio Cassese (Kluwer 2003) 367.

${ }^{45}$ Oxford English Dictionary <www.oxforddictionaries.com> accessed 6 August 2014.
} 
likely to remain unpunished. Access to legal representation is a safeguard that aims to prevent the accused from being unjustifiably punished. Consideration of access to legal representation in admissibility to the ICC will provide guidance to domestic courts about the prosecutorial standards for international crimes. Access to legal representation is a necessary element of justice that will contribute to the prevention of impunity.

\section{d) Deterrence}

The preamble links the prevention of impunity, deterrence and prevention by stating the intention of states 'to put an end to impunity for the perpetrators of these crimes and thus to contribute to the prevention of such crimes'. ${ }^{46}$ Cryer argues that the Rome Statute provides a limited role for deterrence and that it has been undermined in the past by an absence of enforcement and the small number of prosecutions by international criminal tribunals. ${ }^{47}$ Despite this, the application of the rule of law to international crimes provides accountability that can offer some deterrent effect. The Prosecutor argues that the ICC has been an effective deterrent by triggering debate, mobilising the campaign for the release of child soldiers, increasing education, supporting structural reform, and influencing military operational standards. ${ }^{48}$ This has been described as the 'shadow of the court'. ${ }^{49}$ The impact of the 'shadow of the court' depends on its legitimacy.

A failure to consider the accused's rights in the assessment of admissibility communicates a tolerance of national trials that do not provide a fair trial. This undermines legitimacy as it fails to provide determinacy, coherence and adherence to a standard of international criminal justice. ${ }^{50}$ The system of international criminal justice becomes indeterminate and incoherent as different standards are applied by the different organs of implementation. This has the potential to promote injustice and to undermine the legitimacy of international criminal law and its deterrent function. If the ICC is viewed as illegitimate its 'shadow' will have very little impact.

\section{e) Establishment of a Court}

Nouwen argues that the object and purpose of the Rome Statute is simply the establishment of a permanent international criminal court, complementary to national criminal jurisdictions, and

\footnotetext{
${ }^{46}$ Rome Statute (n 1) preamble; Office of the Prosecutor, 'Policy Paper on the Interests of Justice', para 1.

${ }^{47}$ Cryer and others (n 6) 27.

${ }^{48}$ Fatou Bensouda, 'The Rome Statute Ten Years On: Where to from Here for the ICC?' (Melbourne University Law School, 17 February 2011) <www.icc-cpi.int/NR/rdonlyres/F02E8FEF-06B9-4D3E-BF9AB5392EEFA304/0/MelbourneLawSchoollecture.pdf> accessed 6 August 2014, 7-9.

49 Ban Ki-moon 'Address to the Review Conference on the International Criminal Court: "An Age of Accountability"' (Kampala, 31 May 2010)

<www.un.org/sg/selected-speeches/statement_full.asp?statID=829> accessed 6 August 2014.

${ }^{50}$ Franck (n 14) 30-41.
} 
to regulate the conduct of the Court and obligations of states. She states that the Statute's object and purpose is not to be confused with 'lofty aims' in the preamble. ${ }^{51}$ Taking such a limited view separates the Court from its context and fails to consider the inherent functions of a court, one of which is the interpretation of applicable law. The Vienna Convention on the Law of Treaties (VCLT) makes context essential to interpretation, though it provides little guidance on whether to prioritise ordinary meaning, object and purpose, or context, or what meaning to give to these criteria. ${ }^{52}$

The establishment of a court in itself is not an end; it does not achieve anything unless it takes actions relevant to its context. Courts have inherent powers to ensure the proper administration of justice consistent with their judicial functions. ${ }^{53}$ The preamble of the Rome Statute provides guidance on the function of the Court and thus the limits of its inherent powers. ${ }^{54}$ Nouwen argues that this is a misapplication of the preamble as it treats it as legal principle. On the contrary, the preamble addresses the ambiguity of complementarity consistently with the rules of interpretation that permit the use of the preamble to interpret the operative provisions of a treaty. ${ }^{55}$

The ICC has three primary purposes: to function as a permanent international court, to provide international justice and apply the rule of law, and to prevent impunity and promote deterrence. To serve each of these purposes the Court must consider the accused's rights. It is an inherent function of the Court to provide procedural justice. The accused's rights safeguard retributive justice and justice for the victims by preventing the wrongfully accused from being punished. Accordingly, the rights of the accused are important not only for the accused's sake but also because they safeguard justice as a value independent of the accused's dignity. This is essential to ensuring punishment is legitimate. This impacts the effectiveness of the Court in preventing impunity, promoting deterrence, and the application of international criminal justice and rule of law. Without considerations of procedural justice, national proceedings that fail to respect the accused's rights are just as faulty as those that seek to shield the accused, which undermines the legitimacy of international criminal justice.

\footnotetext{
${ }^{51}$ Sarah M H Nouwen, Complementarity in the Line of Fire: The Catalysing Effect of the International Criminal Court in Uganda and Sudan (CUP 2013) 39.

${ }^{52}$ VCLT (n 36) art 31, 32; Julian Mortenson, 'The Travaux of Travaux: Is the Vienna Convention Hostile to Drafting History?' (2013) 107 AJIL 780 820; Yuval Shany, 'Part 3: Questions of Admissibility before International Courts' (Hersch Lauterpacht Memorial Lectures, Cambridge, 1 March 2012) <www.lcil.cam.ac.uk/events/2012lauterpacht-lectures-part-3-questions-admissibility-international-courts> accessed 12 August 2014.

${ }^{53}$ Brown (n 40) 237.

${ }^{54}$ Kleffner (n 8) 100.

${ }^{55}$ VCLT (n 36) art 31; Asylum Case (Colombia v Peru) (Judgment) 1950 ICJ Rep 266, 282; Rights of Nationals of the United States of America in Morocco (France v United States) (Judgment) 1952 ICJ Rep 176, 196.
} 


\section{FROM THEORY TO PRACTICE}

\section{Does complementarity require consideration of the accused's access to legal} representation?

Consideration of the object and purpose of the Rome Statute suggests that complementarity requires consideration of the accused's rights because of their importance to ensuring justice. The language of the Rome Statute leaves several openings for the consideration of the accused's rights in determining admissibility. ${ }^{56}$ These include the applicable law, consideration of 'principles of due process recognized by international law', 'genuinely' carrying out investigation and prosecution, independence and impartiality and 'intent to bring the person concerned to justice', 'substantial collapse' or 'unavailability' of the national judicial system. In using these opportunities the ICC needs to be cognisant of the implications of the imposition of judicial imperialism but also ensure the consistent development of higher standards of justice.

\section{a) Legal framework of complementarity}

The preamble of the Rome Statute emphasises the primary role of national measures in ending impunity, to be enhanced by international cooperation and complemented by the jurisdiction of the ICC. This is reasserted in Article 1, which states that the jurisdiction of the ICC is complementary to national criminal jurisdiction. The ICC's jurisdiction is limited to 'the most serious crimes of international concern' ${ }^{57}$ Complementarity recognised the legal situation prior to the entry into force of the Rome Statute in which national courts were the only method of enforcement, and at times, deficient because of their failure to prevent impunity or provide justice. ${ }^{58}$

Complementarity accommodated criminal jurisdiction as a core component of sovereignty and addressed the enforcement gap in domestic proceedings by conditioning admissibility to the ICC on whether a state is 'unwilling or unable to genuinely carry out the investigation or prosecution'. ${ }^{59}$ A state is considered to be 'unwilling' to do so, if the proceedings were for the purpose of shielding the person from criminal responsibility, if there is an unjustified delay in the proceedings inconsistent with an intent to bring the person

\footnotetext{
${ }^{56}$ Yuval Shany, 'Part 2: The Law Governing Jurisdictional Decision of International Courts' (Hersch Lauterpacht Memorial Lectures, Cambridge, 29 February 2012) <www.lcil.cam.ac.uk/events/2012-lauterpacht- lectures-part2-law-governing-jurisdictional-decisions-international-courts> accessed 12 August 2014.

${ }^{57}$ Rome Statute (n 1) art 1, 5.

${ }^{58}$ Kleffner (n 8) 1.

${ }^{59}$ Rome Statute (n 1) art 17(1); Kleffner (n 8) 1. It also manages the resource constraints of the ICC.
} 
concerned to justice, or if the proceedings were not conducted independently or impartially consistently with an intent to bring the person concerned to justice. ${ }^{60} \mathrm{~A}$ state is considered 'unable' if, 'due to a total or substantial collapse or unavailability of its national judicial system, the state is unable to obtain the accused or the necessary evidence and testimony or otherwise unable to carry out its proceedings', ${ }^{61}$

\section{b) Purpose of complementarity}

Article 17 of the Rome Statute provides the criteria for determining when a case is inadmissible to the ICC. It assumes cases are admissible to the ICC. The Rome Statute preferences trials for international crimes and preventing impunity over state sovereignty. This is balanced against a structure that prioritises national jurisdictions that are willing and able. ${ }^{62}$ If states fulfil their obligations under international law by investigating and prosecuting international crimes, then the Court, recognising the primacy of national jurisdictions, cannot prosecute the case. ${ }^{63}$ This balance recognises the sovereignty of states but allows the ICC to step in where necessary to prevent impunity, implement effective prosecutions, deter future crimes, and maintain the legitimacy of international criminal law. ${ }^{64}$ Though consideration of the rights of the accused are not explicitly included in Article 17, neither are they excluded.

\section{c) Applicable law: human rights in the Rome Statute}

Article 21(3) of the Rome Statute states: '[t]he application and interpretation of law pursuant to this article must be consistent with internationally recognized human rights'. Within the application of the Rome Statute it creates a hierarchy of norms on the basis of subject matter. Article 21(1) sets out the formal sources of law that the Court will apply. These are the Rome Statute, Elements of Crimes and the Court's Rules of Procedure and Evidence, applicable treaties, principles and rules of international law, and general principles of international legal systems. Subsection 3 subjects those sources to being applied and interpreted consistently with the subject matter of internationally recognised human rights law. In this sense, internationally recognised human rights law takes precedence. ${ }^{65}$

\footnotetext{
${ }^{60}$ Rome Statute (n 1) art 17(2).

${ }^{61}$ ibid art 17(3).

${ }^{62}$ Kleffner (n 8) 3; Office of the Prosecutor, 'Paper on Some Policy Issues before the Office of the Prosecutor' 4.

${ }^{63}$ Cryer and others (n 6) 154.

${ }^{64}$ Markus Benzing, 'The Complementarity Regime of the International Criminal Court: International Criminal Justice between State Sovereignty and the Fight against Impunity' (2003) 7 YBUNL 591, 599.

${ }^{65}$ Alain Pellet, 'Applicable Law' in Antonio Cassese, Paola Gaeta and John RWD Jones (eds), The Rome Statute of the International Criminal Court: A Commentary (OUP 2002) 1079; Prosecutor v Lubanga (Jurisdiction) ICC01/04-01/06 (OA4) (14 December 2006) (Lubanga), para 36.
} 
The Rome Statute does not define 'internationally recognized human rights' ${ }^{66} \mathrm{~A}$ starting point is the major international human rights treaties. All of those concerned with civil and political rights recognise the right of an accused individual to access legal representation. ${ }^{67}$ Further, standard rules of treaty interpretation require that complementarity be read consistently with a state's other international obligations. ${ }^{68}$ Therefore, when the Court assesses whether a case is admissible, it should consider whether the state is complying with its international human rights obligations under customary international law, including the right to a fair trial. ${ }^{69}$ Consequently, consideration of 'internationally recognized human rights' includes procedural and substantive due process rights. ${ }^{70}$ This ensures that the procedural availability of rights is not divorced from their purpose to effectively implement justice. ${ }^{71}$ This is supported by the Court in Lubanga, where it states that the application of internationally recognised human rights norms includes 'the right to a fair trial, a concept broadly perceived and applied, embracing the judicial process in its entirety' ${ }^{72}$

Applying article 21(3) of the Rome Statute to admissibility, states must be willing and able to investigate or prosecute in compliance with internationally recognised human rights standards. ${ }^{73}$ Article 21(3) does not bind national jurisdictions but it does bind the ICC. The ICC must apply the criteria of admissibility consistent with 'internationally recognized human rights'. In Al-Senussi, where the Court found the matter inadmissible, the Court recognised the significance of article 21(3). It held that international human rights law was not determinative of admissibility, balancing it against provisions of the preamble to 'guarantee lasting respect for the enforcement of international justice'. ${ }^{74}$

\footnotetext{
${ }^{66}$ Pellet (n 65) 1079.

${ }^{67}$ International Covenant on Civil and Political Rights (adopted 16 December 1966, entered into force 23 March1976) 999 UNTS 171 (ICCPR) art 14(3)(d); Convention for the Protection of Human Rights and Fundamental Freedoms (European Convention on Human Rights, as amended) art 6(3)(c); American Convention on Human Rights (adopted 22 November 1969, entered into force 18 July 1978) 36 OAS art 8(2)(d); African Charter of Human and Peoples' Rights (adopted 27 June 1981, entered into force 21 October 1986) OAU Doc CAB/LEG/67/3 rev 5, 21 ILM 58 (1982) art 7(1)(c); Arab Charter of Human Rights (adopted 15 September 1994, entered into force 15 March 2008) art 16(3); ASEAN Human Rights Declaration (AHRD) (adopted 18 November 2012) Principle 20 (noting that the AHRD is not binding).

${ }^{68}$ VCLT (n 36) art 31(3)(c).

${ }^{69}$ Patrick Robinson, 'The Right to a Fair Trial in International Law, with specific reference to the work of the ICTY' (2009) 3 BJIL 1, 5.

${ }^{70}$ El Zeidy (n 13) 169.

${ }^{71}$ Alex Mills and Kimberley Natasha Trapp, 'Smooth Runs the Water Where the Brook Is Deep: The Obscured Complexities of Germany v Italy’ (2012) 1 CJICL 153, 162; Arrest Warrant of 11 April 2000 (Democratic Republic of the Congo v Belgium) (Separate Opinion of Judges Higgins, Kooijmans and Buergenthal) 2002 ICJ Rep 3, 24.

${ }^{72}$ Lubanga (n 65) 37.

${ }^{73}$ Gioia (n 9) 1115.

${ }^{74}$ Al-Senussi Admissibility Appeal Decision (n 4) 229-230.
} 
The Rome Statute does not require a balancing act, but establishes international human rights law as overriding norms regarding the interpretation of the Rome Statute. In Al-Senussi, the Court held that 'alleged violations of the accused's procedural rights are not per se grounds for a finding of unwillingness or inability under article 17 of the statute'. ${ }^{75}$ Al-Senussi substantiated that he had not had access to legal representation. ${ }^{76}$ This was a breach of international human rights law. Article 21(3) means that the ICC was bound to interpret whether Libya was unwilling and unable in a way that was consistent with international human rights. In finding the case against Al-Senussi inadmissible despite the breach of 'internationally recognized human rights', the ICC has acted inconsistently with the Rome Statute. In assessing national proceedings, the ICC is bound to find proceedings that breach internationally recognised human rights law as admissible to the ICC. Accordingly, the Court's findings in relation to admissibility were not consistent with the application of 'internationally recognized human rights', and were contrary to the binding hierarchy imposed on the interpretation and application of law under the Rome Statute by article 21(3). ${ }^{77}$

d) Unwillingness

i) Principles of due process recognised by international law

The chapeau of article 17(2) of the Rome Statute obligates the Court to 'have regard to the principles of due process recognized by international law'. In this way, the chapeau colours all assessments of unwillingness made by the Court, including whether a state is not genuinely investigating or prosecuting. ${ }^{78}$ In the Ad Hoc Committee some delegations questioned the appropriateness of the Court applying the principles and rules of international law, but ultimately the states parties consented to it. ${ }^{79}$

The principles of due process recognised by international law can be adduced from custom, treaty, internationally recognised principles, and subsidiary sources. ${ }^{80}$ As identified above, these include the right to access legal representation. Consideration of the principles of due process recognised by international law provides greater certainty and somewhat reduces the subjectivity of the standard of 'unwillingness'. It was introduced as an objective criterion. ${ }^{81}$ Further, it is consistent with the object and purpose of the Rome Statute to provide justice, which requires respect for the accused's rights. The Court reasserts the relevance of

\footnotetext{
75 ibid para 231.

${ }^{76}$ Al-Senussi Admissibility Decision (n 13) para 233.

77 VCLT (n 36) art 31(1).

${ }^{78}$ Kleffner (n 8) 116, 127.

${ }^{79}$ Ad Hoc Committee (n 2) para 53.

${ }^{80}$ Statute of the International Court of Justice 18 April 1946 art 38.

${ }^{81}$ Williams and Schabas (n 39) 612.
} 
international standards in the Rules of Procedure and Evidence, which state that the Court may consider internationally recognised norms and standards for impartial and independent prosecution of similar conduct. ${ }^{82}$

In Al-Senussi, the Court limited the applicability of the 'principles of due process recognized by international law' by interpreting it in the context of article 17(2) (a) and (b), which focuses on situations of shielding and unjustified delay. The Court determined the purpose of the provision as preventing the accused from evading justice, which it equated with conviction. ${ }^{83}$ This is an unnecessarily limited view contrary to the explicit language of Article $17(2)$.

ii) Genuinely investigate and prosecute

Article 17(1) provides that a case is admissible to the ICC where "the [s] tate is unwilling or unable genuinely to carry out the investigation or prosecution...'. The term 'genuinely' does not have a clear or objective meaning. This ambiguity of 'genuinely' provides a tool for the ICC to progressively integrate and develop higher international standards of access to legal representation, which will enhance the quality of justice provided by domestic jurisdictions.

The uncertainty surrounding 'genuinely' makes the travaux préparatoires particularly relevant. 'Genuinely' must require an assessment of the investigation or prosecution, as a drafting suggestion that included no adjective was rejected by the drafting conference. ${ }^{84}$ At the Preparatory Committee it was observed that the International Law Commission draft article on admissibility, which made situations under investigation inadmissible, did not take into account the circumstances of the investigation or the possibility of ineffective or unavailable procedures or sham proceedings. ${ }^{85}$ The Preparatory Committee considered that 'genuinely' should take into account the circumstances under which a crime was investigated and the possibilities of ineffective or unavailable procedures. ${ }^{86}$

Delegations to the Rome Statute Conference rejected 'ineffective', 'good faith', 'diligently', and 'sufficient grounds'. 'Genuinely' sought to balance concerns that the Court would consider itself better able to prosecute and investigate than domestic courts and that, if left to their own devices, domestic courts might commit travesties of justice in the name of international criminal law. 'Genuinely' was considered the least subjective because it

\footnotetext{
${ }^{82}$ International Criminal Court, 'Rules of Procedure and Evidence' rule 51.

${ }^{83}$ Al-Senussi Admissibility Appeal Decision (n 4) paras 221, 218.

84 'Report of the Preparatory Committee on the Establishment of an International Criminal Court' UN Diplomatic Conference of Plenipotentiaries on the Establishment of an International Criminal Court (Rome 15 June-17 July 1998) Vol III UN Doc A/CONF.183/2/Add.1(Preparatory Committee Vol III), 28.

${ }^{85}$ Preparatory Committee Vol I (n 37) para 165.

${ }^{86}$ Preparatory Committee Vol III (n 84) 22.
} 
excluded elements of efficiency, while at the same time was more precise than 'sufficient' or 'reasonable grounds'. ${ }^{87}$ The drafters intended to ensure that international crimes would be effectively prosecuted and punished by states, and that 'genuine' seemed more neutral than 'effective' or 'efficient'. ${ }^{88}$ The ambiguity of 'genuinely' allowed the Rome Statute delegation to achieve broad consensus. ${ }^{89}$

Attempts by the delegation to introduce objective criteria failed because the language of the Rome Statute connects genuineness to the criteria of unwillingness and inability. This requires the Court to make an objective assessment of the inherently subjective intentions of the domestic jurisdiction. ${ }^{90}$ To the extent that an objective assessment can be made, this is introduced by interpreting 'genuinely' in the context of the 'principles of due process recognized by international law, ${ }^{91}$ In this way, international law has an objective standard of due process rights that can be assessed by the ICC.

Heller argues that 'genuinely' does not provide an opening for consideration of the accused's access to legal representation. He further suggests that a limited approach to the interpretation of 'genuinely' is supported by the drafting of the Rome Statute that provides detail on the meaning of 'unwilling' and 'unable' in article 17(2) and (3). These provisions focus on situations where an accused will not be tried, which Heller asserts sets the parameters for the interpretation of 'unwilling' and 'unable'.$^{92}$ Even if this is the case, the language of article 17(2) and (3) leaves several openings for the consideration of the accused's rights.

In Al-Senussi, the Court took a narrow view of the requirement of 'genuinely'. It held that 'genuinely' required the taking of 'concrete and progressive investigative steps' to 'ascertain whether the person is responsible for the conduct alleged against him' which may include 'interviewing witnesses or suspects, collecting documentary evidence, or carrying out forensic analyses' ${ }^{93}$ The Court took a subjective approach in determining the requirements of 'genuinely' and failed to utilise the objective standard that is presented in article 17(2) of the 'principles of due process recognized by international law'.

\footnotetext{
${ }^{87}$ John T Holmes, 'Complementarity: National Courts versus the ICC' in Antonio Cassese, Paola Gaeta and John RWD Jones (eds), The Rome Statute of the International Criminal Court: A Commentary (OUP 2002) 674.

${ }^{88}$ Xavier Philippe, 'The Principles of Universal Jurisdiction and Complementarity: How Do the Two Principles Intermesh?' (2006) 88 IRRC 375, 382; Holmes, 'Complementarity: National Courts versus the ICC' (n 87) 6734.

${ }^{89}$ Holmes, 'The Principle of Complementarity' (n 37) 49-50.

${ }^{90}$ Nouwen (n 51) 62.

${ }^{91}$ Rome Statute (n 1) art 17(2); Kleffner (n 8) 116.

92 Heller (n 11) 263.

${ }^{93}$ Al-Senussi Admissibility Decision (n 13) para 66.
} 
iii) Independence, impartiality and 'inconsistent with an intent to bring the person concerned to justice'

Where the domestic jurisdiction does not uphold the accused's rights to access legal representation the proceedings are not being conducted in accordance with these principles. Independence primarily relates to institutional guarantees that ensure judges are independent from the executive and the legislature. ${ }^{94}$ In contrast, "impartiality implies that judges must not harbour preconceptions about the matter put before them, and that they must not act in ways that promote the interests of one of the parties'. ${ }^{95}$ If the domestic jurisdiction does not, in substance, ensure the accused has the right to access legal representation, it suggests a lack of independence, and will inhibit the ability of judges to act impartially.

The Preparatory Committee suggested that this aspect of unwillingness was included to address procedural problems that did not amount to shielding the accused person from being investigated or prosecuted. The purpose of the phrase 'inconsistent with an intent to bring the person concerned to justice' was, it is suggested, in order to prevent impunity where there were insufficient institutional safeguards to ensure the independence of the judiciary to convict, or where the context of the crimes meant that the domestic judiciary would be unable to come to the case without any preconceptions favouring the accused. This is supported by the other elements of unwillingness; unjustified delay, and shielding. ${ }^{96}$ ' $[\mathrm{I}]$ nconsistent with an intent to bring to justice' has a broader application to the protection of the accused's rights in situations where the domestic jurisdiction is too enthusiastic to prosecute. This approach is consistent with the plain meaning of the text, the object and purpose of the ICC to prevent impunity and provide justice, and ensuring that the court maintains its own legitimacy and that of international criminal law.

The phrase 'to bring the person concerned to justice' implies consideration of the accused's rights. ${ }^{97}$ This is especially true when 'bringing to justice' is understood to mean that responsible individuals, and only responsible individuals, are punished. Access to legal representation ensures fairness for the accused and therefore is an essential element of any system of justice. In Lubanga the Court stated '[a] fair trial is the only means to do justice. If no fair trial can be held, the object of the judicial process is frustrated and must be stopped' ${ }^{98}$ Consideration of the accused's access to legal representation is a safeguard for the accused

\footnotetext{
${ }^{94}$ Al-Senussi Admissibility Appeal Decision (n 4) para 250.

${ }^{95}$ Kleffner (n 8) 145.

${ }^{96}$ Holmes, 'The Principle of Complementarity' (n 37) 50-51.

${ }^{97}$ Gioia (n 9) 1111.

${ }^{98}$ Lubanga (n 65) para 37.
} 
from being punished for offences they did not commit. If intervention by the Court were limited to violations of independence and impartiality that only benefited the accused, it 'would be tantamount to frustrating the very objective underlying the reference to "principles of due process recognized by international law". 99

The Court could develop this basis for consideration of the accused's rights by taking into account whether the proceedings are typical to the usual state of practice relating to the investigation and prosecution of serious criminal cases in the state in question. ${ }^{100}$ The Court would need to look beyond the procedural availability of due process rights to consider whether they are substantively available in the particular case. This approach balances the interests of justice and state sovereignty.

Kleffner and Nouwen argue that consideration of due process rights goes beyond the ordinary meaning of 'to bring someone to justice'. ${ }^{101}$ They argue its meaning is limited to arresting and trying someone in a court, based on the dictionary definition, whereas the phrase 'to do justice to someone' would imply a concern for the fairness of the proceedings. ${ }^{102}$ This is a limited view of the meaning of justice which does not consider that both retributive justice and justice for victims require procedural justice. A trial that is not fair does not provide any meaningful form of justice, merely emotional satisfaction that someone, regardless of their responsibility, has been tried. Such a trial is as illegitimate as a trial that seeks to shield the accused and has the further potential to undermine fragile peace in societies divided by conflict. ${ }^{103}$

Nouwen further submits that considering due process rights in relation to admissibility would render the requirements of article 17(2)(b) and (c) - unjustified delay and a lack of independence or impartiality - redundant, as they would be examples of inconsistency with an intent to bring to justice in a fair manner. Considering article 17(2) as a whole, she argues that it is an exhaustive rather than illustrative list of permissible considerations and that if it was intended as an illustrative list, this would be explicit. ${ }^{104}$ However, Nouwen's claim that her approach is supported by the travaux préparatoires is unsubstantiated as they merely show the disagreement between the Parties. The only agreement illustrated by the travaux is

\footnotetext{
${ }^{99}$ Gioia (n 9) 1111.

${ }^{100}$ Holmes, 'Complementarity: National Courts versus the ICC' (n 87) 676.

${ }^{101}$ Rome Statute (n 1) art 17(2).

102 Kleffner (n 8) 151; Nouwen (n 51) 68; for a similar argument see Heller (n 11) 262.

${ }^{103}$ See Section C.

${ }^{104}$ Nouwen (n 51) 68-69.
} 
that the Parties thought the criteria should be clearly defined. ${ }^{105}$ In contrast to Nouwen's suggestions, Robinson argues that article 17(2)(b) was intentionally drafted with the open language of 'shall consider whether' suggesting that the Court may consider these factors, but not limiting any consideration to these factors. ${ }^{106}$ Applying Nouwen's approach ignores the impact that a lack of legal representation can have on the independence and impartiality of a trial. Further a broader reading expands the deterrent effect. ${ }^{107}$ Such substantive considerations are more persuasive in light of the ICC's purpose to provide justice.

In Gaddafi, the Court found that despite procedural guarantees of legal representation, in substance these were not being met, which in part justified admissibility to the ICC. ${ }^{108}$ In Al-Senussi, the Court failed to consider the substantive violations of procedural guarantees to legal representation finding that the case was inadmissible to the ICC. Such conflicting decisions undermine the legitimacy of international criminal law by failing to provide a clear and general application of the law. ${ }^{109}$ Despite the factual similarities, the law applied is conflicting. ${ }^{110}$

In Al-Senussi the Court stated that where "violations of the rights of the suspect are so egregious that the proceedings can no longer be regarded as being capable of providing any genuine form of justice to the suspect ... they should be deemed, in those circumstances, to be "inconsistent with an intent to bring the person to justice". ${ }^{111}$ The Court held, in this context, that a lack of access to legal representation did not meet the threshold. The Court applied a high threshold for the consideration of the accused's rights by characterising a state's challenge to admissibility to the ICC as 'primarily a question of forum' focused on 'the relationship between [s]tates and the Court... ${ }^{112}$ By characterising the dispute as one between states and the Court, the Court made a distinction between procedure and substance that allowed it to focus on whether Al-Senussi had a procedural right to legal representation, as opposed whether this right would be fulfilled in substance. The decision of the Court has

\footnotetext{
105 'Preparatory Committee on International Criminal Court Continues Considering Complementarity between National and International Jurisdictions' (April 2 1996) UN Doc L/2773.

${ }^{106}$ Darryl Robinson, 'Serving the Interests of Justice: Amnesties, Truth Commissions and the International Criminal Court' (2003) 14 EJIL 481, 500.

${ }^{107}$ Christopher Keith Hall, 'Expert Consultation Process on General Issues Relevant to the ICC Office of the Prosecutor: Suggestions Concerning International Criminal Court Prosecutorial Policy and Strategy and External Relations' 15.

${ }^{108}$ Gaddafi Admissibility Decision (n 4) paras 200, 214.

${ }^{109}$ Jutta Brunnée and Stephen J Toope, Legitimacy and Legality in International Law: An Interactional Account (CUP 2010) 6, 26, Lon L Fuller, The Morality of Law (Yale University Press 1969) 33-38.

${ }^{110}$ Al-Senussi Admissibility Appeal Decision (n 4) Separate Opinion of Judge Ušacka para 15.

${ }^{111}$ Al-Senussi Admissibility Appeal Decision (n 4) para 3.

112 ibid para 169.
} 
significance for Al-Senussi as an individual. A lack of access to legal representation is so egregious that it results in no form of justice for the accused because of the important role access to legal advice plays in ensuring that the accused's rights are respected and that their case is adequately presented.

Many argue that the Court is not a human rights body, because there is nothing in the Rome Statute to make the Court responsible for the protection of the accused's rights in the national enforcement of international criminal law, and that this is properly addressed by human rights treaties and bodies. ${ }^{113}$ The Court has held that if this was the purpose, it would expect it to be explicit. ${ }^{114}$ Limiting the consideration of the accused's rights in this way perpetuates injustice contrary to the object and purpose of the Rome Statute. Whether the accused has had access to legal representation in the first instance is an objective standard which the Court could easily make a finding on. As the right develops, the Court may be faced with the more challenging question of adjudicating substantively on the extent of access required to provide a sufficiently fair trial. In Al-Senussi, the Appeal Chamber took a limited view of complementarity that emphasised its role in preventing states from facilitating impunity. ${ }^{115}$ This equates justice with conviction, undermining international criminal justice, contrary to the Court's construction of justice as not always resulting in conviction. ${ }^{116}$ Further, the Court suggested that if the unavailability of due process rights did reach the threshold of warranting admissibility to the ICC, it was open to the Prosecutor to seek review of the Court's decision pursuant to article 19(10). ${ }^{117}$ In effect, the Court is turning the Prosecutor into a human rights monitoring body, contrary to its purpose.

Though human rights treaties and bodies are best placed to address human rights violations in the national enforcement context, the ICC's purpose is to prevent impunity for international crimes within a system of international criminal justice. Failing to consider the accused's rights in domestic processes implements an arbitrary distinction that threatens the integrity of the international criminal legal regime. In sum, the ICC should consider the accused's human rights; the reason for this is not primarily that they are human rights, but that their content contributes to fulfilling the purpose of the Court.

\footnotetext{
${ }^{113}$ Cryer and others (n 6) 156-157; Heller (n 11) 281; Nouwen (n 51) 67-70.

${ }_{114}$ Al-Senussi Admissibility Appeal Decision (n 4) para 219.

115 ibid para 217.

116 ibid para 200

117 ibid para 201.
} 
e) Inability

A state is unable where 'due to a total or substantial collapse or unavailability of a national judicial system the [s]tate is unable to obtain the accused or the necessary evidence and testimony or otherwise unable to carry out its proceedings'. ${ }^{118}$ In the present context, this raises two questions. Firstly, has a national judicial system totally or substantially collapsed if it fails to provide the accused with access to legal representation? Secondly, is a national judicial system unavailable if the accused does not have access to legal representation?

The additional criterion of the inability to obtain the accused or the necessary evidence and testimony clarify the meaning of 'total or substantial collapse' and unavailability of a national judicial system. To prevent the additional criterion from being too restrictive a reference to a state being 'otherwise unable to carry out its proceedings' was included. It was necessary to retain some subjectivity to give the Court latitude to base a finding of unwillingness. ${ }^{119}$ Though 'otherwise unavailable' does not explicitly refer to considerations of the accused's rights, it opens the door for their consideration. ${ }^{120}$

i) Total or substantial collapse of a judicial system

'[T]otal or substantial collapse' establishes a threshold for admissibility to the ICC. Collapse is a situation in which the state cannot fulfil its obligation to investigate or prosecute. ${ }^{121}$ The Rome Statute Conference rejected 'partial collapse' as insufficient to determine inability. ${ }^{122}$ The threshold of 'total or substantial collapse' sought to balance state sovereignty against prevention of impunity and justice. It prevents undue ICC intervention in a judicial system.

In Al-Senussi, the Court relied on evidence that the state had control of the detention facility, judicial proceedings were ongoing, and that hearings were taking place to find that there was not a state of total of substantial collapse of a judicial system. ${ }^{123}$ This limited interpretation of 'total or substantial collapse' undermines the purpose of the Court to provide justice. National judicial systems that do not ensure access to legal representation are unable to deliver justice and are in 'a state of total or substantial collapse'. This interpretation is open to the Court on the ordinary meaning of 'otherwise unable to carry out its proceedings' and supports the object and purpose of the Rome Statute. O'Donohue and Rigney identify that '[f]air

\footnotetext{
118 Rome Statute (n 1) art 17(3).

${ }^{119}$ Holmes, 'The Principle of Complementarity' (n 37) 49-50.

${ }^{120}$ Nouwen (n 51) 64; Holmes (n 86) 678.

${ }^{121}$ Office of the Prosecutor (n 62) 4

122 Holmes, 'The Principle of Complementarity' (n 37) 677; Williams and Schabas (n 39) 612.

${ }^{123}$ Al-Senussi Admissibility Appeal Decision (n 4) para 274.
} 
trial concerns are ... a symptom of a substantially collapsed justice system...' ${ }^{124}$ To meet the threshold of total or substantial collapse the violations of the accused's rights would have to be significant, as opposed to merely not meeting the standards of due process required in the Rome Statute. ${ }^{125}$ This is consistent with the intention that the jurisdiction of the Court would be exceptional. $^{126}$

\section{ii) Unavailability}

Whether a national judicial system is unavailable is also assessed on the additional criterion of 'otherwise unable to carry out its proceedings'. ${ }^{127}$ Kleffner argues that 'unavailability' suggests that the state's national judicial system must constitute a bar to carrying out the proceedings and that due process rights merely relate to the way proceedings are carried out. ${ }^{128}$ In contrast, Nouwen argues that not only practical circumstances but also normative factors can render a system genuinely 'unavailable' to conduct proceedings. ${ }^{129}$ The availability of due process rights is a normative concern of judicial proceedings. Due process rights, that provide procedural justice, allow the Court (or any judicial institution) to achieve, in substance, retributive justice and justice for victims. ${ }^{130}$ Providing justice is an inherent function of the Court that safeguards its judicial character. ${ }^{131}$ O'Donohue and Rigney argue that 'fair trial concerns can render the justice system unavailable to the accused who relies on the fairness of the proceedings to establish their guilt or innocence. ${ }^{132}$ This interpretation is consistent with the object and purpose of the Rome Statute to prevent impunity and provide justice.

Due process rights are relevant where deficiencies in a national investigation or prosecution make it more difficult to convict a suspect because the state's own criminal justice system requires due process. ${ }^{133}$ For example, Libya's Code of Criminal Procedure explicitly guarantees the right to legal representation. Breaches may result in the Libyan national judicial system being unavailable. Allowing admissibility to the ICC where the accused's rights are

\footnotetext{
${ }^{124}$ Jonathan O’Donohue and Sophie Rigney ‘The ICC Must Consider Fair Trial Concerns in Determining Libya’s Application to Prosecute Saif Al-Islam Gaddafi Nationally' (EJIL: Talk, 8 June 2012) <www.ejiltalk.org/theicc-must-consider-fair-trial-concerns-in-determining-libyas-application-to-prosecute-saif-al-islam-gaddafinationally/> accessed 9 January 2014.

${ }^{125}$ Frédéric Mégret and Marika Giles Samson, 'Holding the Line on Complementarity in Libya The Case for Tolerating Flawed Domestic Trials' (2013) 11 JICJ 571, 577-581, 585-586.

${ }^{126}$ Ad Hoc Committee (n 2) para 47; Preparatory Committee Vol I (n 37) para 154.

${ }^{127}$ Rome Statute (n 1) art 17(3).

${ }^{128}$ Kleffner (n 8) 157.

${ }^{129}$ Nouwen (n 51) 65.

${ }^{130}$ Mills and Trapp (n 71) 160,163.

${ }^{131}$ Gaeta (n 44) 355.

132 O’Donohue and Rigney (n 124).

${ }^{133}$ Kevin Jon Heller 'Why the Failure to Provide Saif with Due Process is Relevant to Libya's Admissibility Challenge' (Opinio Juris, 2 August 2012) <http://opiniojuris.org/2012/08/02/why-the-failure-to-provide-saifwith-due-process-is-relevant-to-libyas-admissibility-challenge/> accessed 18 August 2014.
} 
violated would balance the interest in preventing impunity and would require evidence that meets international standards of due process. Relevantly, in Gaddafi, the Court found that the case was admissible, partly, because Libya was 'otherwise unable', as Gaddafi did not have access to legal representation. ${ }^{134}$ Here, the accused's rights were relevant. In contrast, in $\mathrm{Al}$ Senussi, the Court considered the procedural rights provided in Libya's Code of Criminal Procedure acceptable protection in relation to the preliminary stage of the investigation. ${ }^{135}$ The Libyan government made the same assertions about efforts to obtain legal counsel for both Gaddafi and Al-Senussi. ${ }^{136}$ In Al-Senussi, the Court failed to lift the veil of procedure and consider the substantive practice of the state. Such inconsistency undermines the international criminal legal regime. ${ }^{137}$

\section{f) Summary}

There are a number of options when it comes to the ICC's considering the accused's rights to access to legal representation in admissibility determinations. All of these facilitate the purpose of the ICC to prevent impunity, implement justice, and apply principles of the rule of law. Article 21(3) makes internationally recognised human rights law a binding norm on the interpretation of the Rome Statute and is consistent with states' other human rights obligations. 'Genuinely' is sufficiently ambiguous to allow discretion to the Court to consider the availability of the accused's rights. A lack of legal representation may prevent proceedings from being independent or impartial and be inconsistent with an intent to bring the accused to justice because the accused does not have the safeguards that prevent wrongful punishment and may prevent the Court from being fully informed of all the facts and arguments. Consideration of the availability of the accused's rights requires the Court to consider the substantive availability of the rights to ensure the coherent and legitimate development of international criminal law. In defining 'unable', states gave the Court discretion to consider whether a domestic jurisdiction was 'otherwise unable to carry out its proceedings'. This creates an opening for normative considerations including the accused's rights. Failure to provide due process rights may prevent a domestic court from providing justice which should be considered 'a state of total or substantial collapse'. A lack of due process rights can render a domestic court unavailable to the accused as it may not be able to provide the accused with

\footnotetext{
${ }^{134}$ Gaddafi Admissibility Decision (n 4) para 213.

${ }^{135}$ Al-Senussi Admissibility Decision (n 13) para 233.

${ }^{136}$ Kevin Jon Heller 'PTC I's Inconsistent Approach to Complementarity and the Right to Counsel' (Opinio Juris, 12 October 2013) <http://opiniojuris.org/2013/10/12/ptc-inconsistent-approach-right-counsel/> accessed 1 July 2014.

137 See Section B.
} 
justice. It is open to the Court to consider the availability of due process rights in determining admissibility to the ICC.

2. Does consideration of the accused's access to legal representation undermine the legitimacy and effectiveness of the ICC?

The legitimacy and effectiveness of an international court are not solely determined by providing justice. By upholding an international standard of due process rights, the ICC runs the risk of being criticised for judicial imperialism. If the ICC is, or is perceived to be, an instrument of political power, it undermines its legitimacy and effectiveness as a judicial organ. This may provide impetus for states to refuse to cooperate with the ICC. Further, an overzealous approach to due process rights has the potential to undermine the value of local justice, the reconstruction of domestic rule of law, and reconciliation. However, providing due process rights is essential for these issues to be addressed by domestic jurisdictions. It is the legitimate role of the Court to address the lacunae of the Rome Statute by establishing higher standards of access to legal representation. ${ }^{138}$ It is the role of the Court to create a space for interaction between the Parties to create a practice of legality that develops the standards of admissibility. ${ }^{139}$

\section{a) Judicial imperialism}

Consideration of the accused's access to legal representation in determining admissibility to the ICC will result in an assessment by the Court of each particular case. ${ }^{140}$ The intervention of international criminal law in national jurisdictions is justified on the basis that it lifts the proceedings out of a political context. International trials have the advantage of international standards and forums that are more likely to uphold the rule of law and satisfy fairness and impartiality concerns. ${ }^{141}$ However, the political nature of referrals to the ICC can give rise to the appearance of judicial imperialism. Furthermore, the ICC's dependency on the support of powerful states can result in the Prosecutor's powers only being used against weak states. ${ }^{142}$ Though designed as an independent office, it is likely that the Prosecutor will exercise its functions in a way that sustains support for the institution from the most powerful states. Even when the prosecutor opens a preliminary investigation into a more powerful state, such as that of the British forces in Iraq, ${ }^{143}$ it is highly unlikely that this will ever reach

\footnotetext{
138 Gaeta (n 44) 367.

${ }^{139}$ Brunnée and Toope (n 109) 5, 6, 353.

${ }^{140}$ Al-Senussi Admissibility Appeal Decision (n 34; Gaddafi Admissibility Appeal Decision (n 13).

${ }^{141}$ Ruti G Teitel, Transitional Justice (OUP 2000) 33.

142 Nouwen (n 51) 14.

143 'Prosecutor of the International Criminal Court, Fatou Bensouda, Re-Opens the Preliminary Examination of the Situation in Iraq' (International Criminal Court, 13 May 2014)
} 
prosecution because of the sophisticated judicial system in the United Kingdom. A closer look at the cases before the ICC and how they came about reveals the following picture.

The cases of Darfur and Libya have been triggered by United Nations Security Council referral. ${ }^{144}$ Neither Sudan nor Libya are parties to the Rome Statute. Three of the five members of the Security Council - the United States, Russia, and China - are notp Parties to, or have not ratified, the Rome Statute. ${ }^{145}$ Security Council resolutions are inherently political and reflect existing power structures. ${ }^{146}$ Sudan has refused to cooperate with the ICC, preventing investigation and prosecution. The situations in Kenya and Côte d'Ivoire were triggered by the Prosecutor's proprio motu powers. ${ }^{147}$ Libya and Kenya have opposed admissibility to the ICC, citing consent as the basis of the Court's legitimacy. ${ }^{148}$

In addition to those cases mentioned so far, the contrasting decisions in Gaddafi and Al-Senussi leave the Court open to criticism that it is applying the law in a way that is inconsistent with the basic principle that cases that are the same should have the same result. ${ }^{149}$ After the decision in Gaddafi, the African Union (AU) declared that it would hold a summit on the withdrawal of African states from the ICC. ${ }^{150}$ On 11 October 2013, the ICC held that the case against Al-Senussi was inadmissible. On 12 October, at the AU Summit, the AU declared its concerns about the politicisation and misuse of indictments against African leaders by the ICC. ${ }^{151}$ To date, no African state has withdrawn from the ICC. The AU's response to the ICC's focus on Africa demonstrates that '[i]nternational criminal justice ... cannot enjoy long-term credibility if it becomes an instrument of hegemony for powerful [s]tates' ${ }^{152}$ If the ICC is

\footnotetext{
<www.icc-cpi.int/en_menus/icc/press\%20and\%20media/press\%20releases/pages/otp-statement-iraq-13-052014.aspx > accessed 28 July 2014.

${ }^{144}$ UNSC Resolution 1593 (31 March 2005) S/RES/1593 (2005), UNSC Resolution 1970 (26 February 2011) S/RES/1970 (2011); Nouwen (n 51) 403.

${ }^{145}$ United Nations Treaty Collection

<https://treaties.un.org/pages/ViewDetails.aspx?src=TREATY\&mtdsg_no=XVIII-

10\&chapter=18\&lang=en\#11> accessed 14 August 2014.

${ }^{146}$ United Nations Charter (adopted 26 June 1945, entered into force 24 October 1945) art 23, 27; Shany, 'Part

3: Questions of Admissibility before International Courts' (n 52).

${ }^{147}$ Situation in the Republic of Kenya (Decision authorizing an investigation) ICC-01/09 (31 March 2010) Situation in the Republic of Cóte d'Ivoire (Decision authorizing an investigation) ICC-02/11 (3 October 2011).

${ }^{148}$ Shany, 'Part 1: The Concept of Jurisdiction and Admissibility in International Adjudication - a Theoretical Framework' (n 43).

${ }^{149}$ Shany, 'Part 2: The Law Governing Jurisdictional Decision of International Courts' (n 56).

150 'African Union Summit on ICC Pullout' (BBC, 20 September 2013) <www.bbc.co.uk/news/worldafrica-24173557> accessed 26 June 2014.

${ }^{151}$ Summits (African Union 12 October 2013)

<http://summits.au.int/en/sites/default/files/Ext\%20Assembly\%20AU\%20Dec\%20\&\%20Dec1\%20_E.pdf> accessed 26 June 2014.

152 Payam Akhavan, 'Beyond Impunity: Can International Criminal Justice Prevent Future Atrocities?' (2001) 95 AJIL 7, 30.
} 
viewed as an instrument of power rather than justice it will not be viewed as legitimate by states parties. ${ }^{153}$ This has the potential to result in their withdrawal. ${ }^{154}$

Damaška highlights that even where the Court disproportionately prosecutes weak nations, 'international criminal courts contribute to the emergence of a moral climate in which even big and powerful actors in the international arena find it increasingly difficult to ignore their verbal commitments. ${ }^{155}$ It is arguable, and has at times been perceived, that investigations and prosecutions of the Court are not politically neutral. Despite this, the Court has a normative impact on the behaviour of all states. ${ }^{156}$ Still, the regional imbalance in prosecutions has created a perception of illegitimacy.

Without the cooperation of states or consent to its jurisdiction, the ICC cannot function. ${ }^{157}$ In cases like Al-Senussi, where the state is clearly willing to prosecute the accused, the ICC has considered the perceived legitimacy of the Court in focusing on the procedural rather than substantive access to legal representation. Here, the Court walks a tightrope between its legitimacy to states parties, its legitimacy as a judicial organ and its effectiveness.

b) The value of local justice

If the ICC required states to have in place due process rights equivalent to the Rome Statute for a matter to be inadmissible to the ICC, it would have the potential to undermine the value of local justice. Domestic criminal prosecutions conducted within post-conflict societies are presumed to contribute to societal reconstruction and the transition to peace by consolidating trust in the national judiciary and rule of law, diminishing the risk of vigilante justice and general scepticism towards the political system and giving societies ownership of the justice process. ${ }^{158}$ If the ICC determines that a lack of due process rights makes a matter admissible to the ICC, the ability of domestic trials to play this role is limited. These were potentially underlying policy considerations in Al-Senussi. Transitional justice relies on a pragmatic normative construction of the new political regime. Criminal sanctions in the transitional context seek to address the illegitimacy of the past rule.

\footnotetext{
${ }^{153}$ Shany, 'Part 3: Questions of Admissibility before International Courts' (n 52).

${ }^{154}$ Brunnée and Toope (n 109) 124; Preparatory Committee Vol III (n 84) para 163.

${ }^{155}$ Brunnée and Toope (n 109) 363.

156 ibid 92.

157 Timothy Waters 'Let Tripoli Try Saif Al-Islam: Why the Qaddafi Trial Is the Wrong Case for the ICC' (2011) Foreign Affairs <www.foreignaffairs.com/articles/libya/2011-12-09/let-tripoli-try-saif-al-islam> accessed 7 August 2015.

${ }^{158}$ Cryer and others (n 6) 38; Nouwen (n 51) 333; Kleffner (n 8) 31; Gaddafi Admissibility Appeal Decision (n 13) Dissenting opinion of Judge Ušacka para 55.
} 
Teitel argues that this may justify moving outside the law to address past injustices. ${ }^{159}$ If the ICC ignores violations of the accused's rights it can contribute to it becoming a feature of the new political order. ${ }^{160}$ The Rome Statute gives the ICC the mandate to move states in a hegemonic direction in determining how to address the prosecution of crimes within its jurisdiction. ${ }^{161}$ The Court can achieve this without undermining states parties' sovereignty through complementarity. Complementarity requires states to have the shared objective of effective prosecution. ${ }^{162}$ The Court could take a pluralist approach that is tolerant of different types of conduct but does not validate any and all conduct. ${ }^{163}$ This approach promotes autonomy, facilitates communication, and protects diversity. ${ }^{164}$

States should be required to provide a right to access legal representation. In cases where the accused has no or an extremely limited right to access legal representation, there is a clear violation that the Court should remedy through admissibility. Such a decision protects the comprehensive judicial character of the Court, the legitimacy of international law and the development of rule of law in transitional societies. ${ }^{165}$

By upholding international standards of due process, the ICC has the potential to induce higher standards in domestic judicial institutions, to the detriment of the benefits that can be derived from the experience of transitional justice. ${ }^{166}$ International criminal law and procedure can fulfil a mediating role in transitional justice as it remains intact despite the collapse of the domestic jurisdiction, has the capacity to comprehend extraordinary violence, and is well suited to express the transitional message of a normative shift. ${ }^{167}$ The Court must balance the value of local justice to reconstruction and reconciliation against the international community's interest in preventing impunity and the development of an international rule of law in each context. ${ }^{168}$

\footnotetext{
159 Teitel (n 141) 13, 26.

160 ibid 26.

${ }^{161}$ Bluemenson (n 28) 849.

${ }^{162}$ Adrian Bos 'From the International Law Commission to the Rome Conference (1994-1998)' in Antonio Cassese, Paola Gaeta and John RWD Jones (eds), The Rome Statute of the International Criminal Court: A Commentary (OUP 2002) 44.

163 Bluemenson (n 28) 857, 866.

${ }^{164}$ Brunnée and Toope (n 109) 33.

165 Case Concerning the Northern Cameroons (Cameroon v UK) 1963 ICJ Rep 15, 38.

${ }^{166}$ David Luban, 'After the Honeymoon Reflections on the Current State of International Criminal Justice' (2013) 11 JICJ 505, 509.

167 Teitel (n 141) 20, 30.

168 Shany, 'Part 3: Questions of Admissibility before International Courts' (n 52); Report of the Secretary-General 'The Rule of Law and Transitional Justice in Conflict and Post-Conflict Societies' (2011) UN Doc S/2011/654 1.
} 
Where a state is overly willing to prosecute, to the extent that there is no possibility of providing any genuine form of justice, permitting domestic prosecution undermines international and domestic rule of law. Such trials contribute to the normative construction of a domestic and international political regime that fails to respect rights. This undermines both domestic and international justice because of the important role that legal representation plays in ensuring procedural justice. The risk for the Court is that it will provide conflicting decisions that will undermine international rule of law and its own legitimacy, as occurred in the Gaddafi and Al-Senussi decisions. ${ }^{169}$

\section{c) Development of an international standard of justice}

Legitimacy and effectiveness cannot be divorced as an ineffective court may lose legitimacy and vice versa. A court must retain a minimum level of legitimacy and effectiveness to be operational. If a court does not meet minimum standards of legitimacy and effectiveness, matters will not be referred to it for determination, nor will its judgments be enforced. ${ }^{170}$ The implementation of an international standard of due process rights in domestic proceedings would address these concerns and fulfil the previous Prosecutor's vision of success: 'the absence of trials before ... [the] Court, as a consequence of the regular functioning of national institutions... .171

The ICC provides a forum for the development of shared understandings and the development of a practice of legality that implements interactional international law. ${ }^{172}$ Pursuant to the Rome Statute, states parties have agreed that those responsible for the most serious international crimes should be tried where states are unwilling and unable to do so. The parties left a lacuna in terms of what 'unwilling' and 'unable' mean, that the Court is required to fill. Using the consideration of the rights of the accused to fill this lacuna is justified by the purpose of the Court and the language of article 17. Through its judgments, the Court signals to states parties what actions are required for their courts to be considered willing and able to try those accused of international crimes. If states seek to avoid matters being removed from domestic jurisdiction and admitted to the ICC, they will implement the standards used by the ICC to determine admissibility. A shared understanding is developed through states' further

\footnotetext{
${ }^{169}$ Al-Senussi Admissibility Appeal Decision (n 4) Separate Opinion of Judge Ušacka para 15; Shany, 'Part 3: Questions of Admissibility before International Courts' (n 52).

${ }^{170}$ Shany, 'Part 2: The Law Governing Jurisdictional Decision of International Courts' (n 56).

${ }^{171}$ Luis Moreno-Ocampo 'Ceremony for the solemn undertaking of the Chief Prosecutor of the International Criminal Court' 16 June 2003.

172 Al-Senussi Admissibility Appeal Decision (n 4) Separate Opinion of Judge Ušacka para 9; Prosecutor v Ruto et al (Decision on Admissibility of the Case Pursuant to Article I9(2)(b) of the Statute) (20 September 2011) ICC-01/09-01/11-336 (OA) Dissenting Opinion of Judge Ušacka para 19.
} 
interactions with the Court. Specifically, in the context of the ICC, this shared understanding is developed through subsequent referral of matters by states, the Security Council and individuals to the Court. This signals acceptance of the continuing authority of the ICC.

If the Court does not consider the accused's rights, it misses an opportunity to develop the law and creates a sense of hypocrisy that damages commitment to the rule of law. ${ }^{173}$ The implementation of static law that disregards context will detract from the development of a shared understanding that contributes to the legitimacy of international law. ${ }^{174}$ Failure to consider the availability of due process rights or providing conflicting decisions undermines the judicial function of the Court. International legal obligations are effective when the norms of international law apply the criteria of legality to practice. Consideration of access to legal representation is relevant to maintaining the consistency, congruence, and non-contradiction of judicial function in international law. Ignoring key safeguards of the judicial process undermines certainty and detracts from the practice of legality and sense of legal obligation of states to uphold the accused's rights. ${ }^{175}$ In the context of international criminal law, it is likely to be more difficult for states to uphold their international human rights obligations. The consideration of the accused's rights in admissibility to the ICC provides a further possible enforcement mechanism.

Imposing the standard of due process rights provided in the Rome Statute would have a disproportionately detrimental impact on the legitimacy of the ICC. It would reinforce claims of judicial imperialism and undermine reconstruction. The Court should initially hold states to their existing human rights obligations and the principle of due process recognised by international law to provide access to legal representation. At the same time, the Court should accept a plurality of models regarding the form this access may take. Such an approach would establish a base standard that could be developed through the jurisprudence of the ICC as a forum of interaction to enhance the shared understanding that forms the basis of legal legitimacy.

As an organ applying international law, the ICC is caught in a tension between the application of law and politics. In contrast to a domestic court, it has to consider its legitimacy as perceived by sovereign states, as it depends on them for its effective operation. Maintaining this support can undermine the rule of law. ${ }^{176}$ Cynics will see this as a failure of the Court.

\footnotetext{
${ }^{173}$ Al-Senussi Admissibility Appeal Decision (n 4) Separate Opinion of Judge Ušacka para 9.

${ }^{174}$ Brunnée and Toope (n 109) 24.

175 ibid 41; Shany, 'Part 3: Questions of Admissibility before International Courts' (n 52).

176 Shany, 'Part 3: Questions of Admissibility before International Courts' (n 52).
} 
However, this fails to recognise that the Court is in a developmental stage and that the international community has taken a great leap towards the implementation of international rule of law in the establishment of the ICC. ${ }^{177}$ To maintain legitimacy, the Court cannot take an overzealous approach to ensuring that the accused has access to legal representation, but must rather take a pluralist approach that accepts that access may take varied forms. It must also set progressively evolving minimum standards. This is not ideal from a rule of law perspective but will hopefully achieve the final objective of the implementation of an international standard of access to legal representation in domestic courts.

\section{CONCLUSION}

The establishment of a permanent international court, the prevention of impunity and promotion of deterrence, and the establishment of international justice and rule of law require that the ICC is perceived as a legitimate institution of international law. The ICC will not prevent impunity or be a deterrent if it is not considered to provide procedural justice. If the ICC does not consider the accused's rights at a domestic level in determining admissibility it will not provide retributive justice or justice for victims, because access to legal representation is essential to ensuring that the accused is not wrongly convicted. The ICC must consider the accused's rights in determining admissibility; when domestic courts prosecute international crimes they act as agents of international criminal law. Failure to consider the accused's rights undermines the legitimacy of international criminal justice.

The text of the Rome Statute provides openings for the Court to consider the availability of due process rights in determining admissibility. The Court is required to apply the Rome Statute consistently with international human rights law. The requirement that investigations and prosecutions are genuine provides an ambiguous criterion that allows the Court to make an assessment of domestic investigations and prosecutions. Unwillingness is to be assessed in light of the 'principles of due process recognized by international law' and in a manner 'not inconsistent with an intent to bring the person concerned to justice', which requires access to legal representation. 'Unable' includes whether 'due to a total or substantial collapse of the national judicial system, the state is otherwise unable to carry out its proceedings'. Violations of the accused's access to legal representation represents a substantial collapse of a legal system, as it is essential to ensuring the legitimacy of a court. Violations of the accused's rights

\footnotetext{
${ }^{177}$ Shany, 'Part 1: The Concept of Jurisdiction and Admissibility in International Adjudication - a Theoretical Framework' (n 43).
} 
makes a court 'otherwise unable' to prosecute, as protection of the accused's rights is an inherent function of a court. Finally, the Court may consider that a domestic court is unavailable to the accused where it does not provide access to legal representation as this is not legitimately fulfilling its purpose of providing a fair trial. Considering the accused's rights is consistent with the overarching purpose of the ICC to provide international justice.

If the ICC takes an assertive role in determining cases as admissible based on violations of the accused's rights at the domestic level, it may face challenges to its legitimacy. These challenges include claims of judicial imperialism and of undermining local justice and undermine the effectiveness of the Court as States may withdraw from the Rome Statute or refuse to cooperate - which may have the same effect, given the ICC's reliance on state cooperation for implementation and enforcement. Removing cases from domestic courts potentially deprives the local community of the opportunity to strengthen domestic rule of law and facilitate reconciliation. Creating a system where some accused of international crimes have access to the highest standard of due process rights and others do not has the potential to create two (or several) standards of justice breeding injustice. The Court must be aware of the context it operates within to maintain its legitimacy and effectiveness. The Court should not insist that domestic jurisdictions provide the same level of due process rights as provided in the Rome Statute, but should take a pluralist approach that ensures basic standards are met. As the international criminal legal system develops, the ICC should give greater weight to considerations of access to legal representation and hold States to a higher standard of international criminal justice. 